\title{
EFEKTIFITAS PROGRAM BINA KELUARGA BALITA
}

\author{
Oleh : \\ Resti Fauziah, Nandang Mulyana, Santoso Tri Raharjo \\ FISIP Universitas Padjadjaran, \\ Jl. Raya Bandung-Sumedang Km. 21 Jatinangor 45263 \\ resfauziah@gmail.com
}

\begin{abstract}
Effectiveness of Bina Keluarga Balita Programme Implementation. BKKBN develop a toddler family building program or BKB which aims to improve the comprehension and skills of parent in children nurture. The purpose of this study is to determine and describe the effectiveness of BKB program implementation. Study about effectiveness done to know the achievement of a family building program. This study conducted in Jamika Sub-district of Bojongloa Kaler Bandung with respondents are program implementor which consisting of cadre and parents become the participant. Data collected from respondents with questionnaire and supported by unstructured interviewing. The sampling method uses is proportional random sampling with a sample size of 60 respondents divided into two groups: cadre and program participants. Analysis techniques used descriptive quantitative then hypothesis tested using the formulas of T-Test and $Z$-Test. Hypothesis advanced by researcher says effectiveness toddler family building program implementing in Jamika Sub-district least $60 \%$ of the ideal value. Thus if null hypothesis accepted, it means toddler family building program implementing in Jamika Sub-district already run effective or very effective.
\end{abstract}

Keywords : BKB Programs, effectiveness, family building.

\begin{abstract}
Abstrak: Efektifitas Pelaksanaan Program Bina Keluarga Balita. BKKBN mengembangkan program Bina Keluarga Balita (BKB) yang bertujuan untuk meningkatkan pemahaman dan keterampilan orang tua dalam pengasuhan anak balita. Tujuan penelitian ini adalah untuk mengetahui dan mendeskripsikan efektifitas pelaksanaan program Bina Keluarga Balita. Pengkajian efektitas dilakukan agar dapat mengetahui hasil pencapaian dari suatu program pembinaan keluarga. Penelitian ini dilaksanakan di Kelurahan Jamika Kecamatan Bojongloa Kaler Kota Bandung dengan responden penelitian ialah pelaksana program yang terdiri dari kader dan orang tua balita yang menjadi peserta. Pengumpulan data dari responden diperoleh melalui kuesioner serta didukung oleh wawancara tidak terstruktur. Pengambilan sampel menggunakan teknik proporsional random sampling dengan jumlah sampel sebanyak 60 responden yang dibagi kedalam dua kelompok yaitu kader dan peserta program. Teknik analisa data yang digunakan yaitu deskriptif kuantitatif kemudian hipotesis diuji dengan menggunakan rumus uji-T dan uji-Z. Hipotesis yang dikemukakan oleh peneliti berbunyi efektifitas pelaksanaan program Bina Keluarga Balita di Kelurahan Jamika paling rendah $60 \%$ dari nilai ideal. Dengan demikian bila hipotesis nol diterima maka pelaksanaan program Bina Keluarga Balita di Kelurahan Jamika sudah berjalan cukup efektif atau sangat efektif.
\end{abstract}

Kata Kunci : Program BKB, Efektifitas, Pembinaan Keluarga. 


\section{PENDAHULUAN}

Masalah kependudukan dan masalah sosial merupakan dua cakupan atau bidang yang memiliki keterkaitan sangat erat. Indra (2010) mengungkapkan masalah kependudukan misalnya laju pertumbuhan penduduk yang terlalu cepat di suatu daerah terutama daerah perkotaan akan berdampak pada kemunculan masalah-masalah sosial yang semakin rumit seperti meningkatnya jumlah pengangguran karena lahan pekerjaan yang semakin berkurang. Laju pertumbuhan penduduk yang cepat dan dinamika masyarakat yang umumnya terjadi pada daerah perkotaan ini melahirkan isu-isu yang berkaitan dengan kesejahteraan masyarakat salah satunya kesejahteraan anak. Demikian halnya diungkapkan oleh BPPKB Kota Bandung (2011): "Terdapat beberapa isu yang sejalan dengan dinamika dan perkembangan masyarakat perkotaan. Isu isu yang berkaitan dengan bidang pemberdayaan perempuan yaitu rendahnya kesejahteraan dan perlindungan anak seperti eksploitasi terhadap anak, penelantaran dan kekerasan terhadap anak." Pernyataan tersebut didukung oleh data laporan pelayanan terhadap anak dan perempuan korban kekerasan BPPKB Kota Bandung pada triwulan ke-IV tahun 2013 dimana kasus terbanyak yaitu terjadi pada kategori usia 017 tahun dengan jumlah 29 kasus. Data terbaru BPPKB Kota Bandung menggambarkan bahwa perlakuan salah terhadap anak masih kerap terjadi hingga saat ini. Dalam mengurangi jumlah permasalahan anak akibat perlakuan salah tersebut tentunya diperlukan tindakan pencegahan dan penanganan secara maksimal. Tindakan maksimal ini tidak akan terwujud tanpa adanya peran serta keluarga. Pasalnya, keluarga merupakan satu unit yang memiliki peranan sangat mendasar dalam pengasuhan dan pendidikan anak karena disanalah tempat utama anak menjalani proses tumbuh kembang.

Tanggung jawab keluarga dan orang tua dalam melaksanakan kewajibannya yaitu mendidik dan mengasuh anak merupakan aspek yang perlu diperhatikan. Masih adanya perlakuan-perlakuan yang seharusnya tidak didapatkan oleh anak sebagai calon generasi unggul menjadi hal yang sangat disayangkan. Keadaan tersebut menafsirkan bahwa untuk dapat tumbuh dan berkembang dengan baik, maka orang tua dan keluarga perlu memiliki keterampilan dan kapasitas dalam pengasuhan anak. Anak merupakan investasi keluarga yang paling berharga bagi setiap keluarga. Anak merupakan investasi keluarga yang paling berharga bagi setiap keluarga. Dalam perkembangannya, anak memiliki masa yang sangat membutuhkan daya dukung keluarga yang memadai bagi terpenuhinya hak-hak anak pada masa tersebut. Berdasarkan maknanya, masa tersebut disebut sebagai masa keemasan atau golden age . periode golden age dapat dikategorikan sebagai periode paling kritis dalam menentukan Sumber Daya Manusia karena proses pertumbuhan berlangsung sangat cepat. Masa ini dapat diibaratkan sebagai sebuah fondasi dalam pembentukan 
karakter anak. Dalam hal ini, maka keluarga sebagai lingkungan sosial yang paling dekat dengan anak memiliki peran yang sangat penting dalam pembentukan generasi yang unggul dan berkualitas.

Upaya peningkatan kualitas dan kesejahteraan keluarga itu sendiri dilakukan pemerintah melalui pembinaan terhadap keluarga. Berdasarkan Undang-Undang nomor 52 Tahun 2009 Tentang Perkembangan Kependudukan dan Pembangunan Keluarga Pasal 47, mengamanatkan bahwa pemerintah dan pemerintah daerah menetapkan kebijakan pembangunan keluarga melalui pembinaan ketahanan dan kesejahteraan keluarga. Salah satu bagian dari program pembinaan ketahanan keluarga tersebut ialah Bina Keluarga Balita (BKB). Bina Keluarga Balita (BKB) merupakan salah satu program yang bertujuan untuk meningkatkan pemahaman dan keterampilan ibu dalam pengasuhan dan pendidikan anak.

\section{HASIL DAN PEMBAHASAN}

Pembinaan keluarga dalam upaya meningkatkan peran keluarga untuk perlindungan anak dan pemenuhan kebutuhan anak merupakan fungsi utama praktik pekerjaan sosial pada sistem kesejahteraan anak. Hal ini seiring dengan pendapat Petr (2004) yang mengemukakan bahwa tiga fungsi atau tujuan utama praktik pekerjaan sosial pada sistem kesejahteraan anak diantaranya: perlindungan anak, pemeliharaan atau pembinaan keluarga, dan perencanaan jangka panjang. Berdasarkan penjelasan tersebut dapat diperoleh gambaran bahwa karakteristik program Bina Keluarga Balita memiliki kaitan yang cukup erat dengan fungsi utama praktik pekerjaan sosial pada sistem kesejahteraan anak.

Selama ini pelaksanaan Program Bina Keluarga Balita telah dirintis sejak tahun 1984 (BKKBN). Di Kecamatan Bojongloa Kaler, pelaksanaan program Bina Keluarga Balita mengalami penurunan yang ditandai dengan semakin semakin terbatasnya jumlah kelompok yang ada di tiap-tiap Kelurahan. Jumlah balita di Kecamatan Bojongloa Kaler saat ini yaitu 8486 balita. Jumlah anggota setiap satu kelompok BKB adalah 25 balita dengan kategori umur 0-5 tahun. Kategori tersebut diklasifikasikan kedalam lima jenjang umur diantaranya 0-1 tahun, 1-2 tahun, 2-3 tahun, 3-4 tahun, dan 4-5 tahun sehingga satu jenjang terdapat lima orang peserta (BKKBN). ). Mengacu pada jumlah balita dan jumlah RW di Kecamatan Bojongloa Kaler yang seluruhnya berjumlah 47 maka idealnya setiap RW minimal memiliki satu atau dua kelompok BKB. Namun saat ini kelompok BKB di Kecamatan Bojongloa Kaler hanya berjumlah 5 kelompok bahkan tidak semua kelurahan memiliki kelompok BKB. Koordinator KB Kecamatan Bojongloa Kaler menjelaskan beberapa permasalahan mengenai pelaksanaan program BKB saat ini diantaranya: 1) Kurangnya pengetahuan masyarakat mengenai program BKB, 2) Kurangnya peran serta masyarakat terhadap program BKB, 3) Jumlah koordinator lapangan sangat terbatas. (Hasil Penelitian, 2014) 
Berangkat dari urgensi program Bina Keluarga Balita dalam peningkatan kapasitas pengasuhan orang tua dan keluarga terhadap anak serta permasalahan program yang telah diungkapkan, peneliti bermaksud untuk mengkaji mengenai efektifitas pelaksanaan program Bina Keluarga Balita. Penelitian ini menjadi penting untuk dilakukan agar diperoleh informasi yang mendalam untuk perbaikan program kedepan. Dengan mempertimbangkan keterbatasan peneliti, maka penelitian hanya dilakukan di salah satu kelurahan yang memiliki dua kelompok BKB yaitu Kelurahan Jamika Kecamatan Bojongloa Kaler. Pengukuran efektifitas program merupakan salah satu cara untuk melihat dan menganalisis pencapaian tujuan dari program tersebut. Dalam pengukuran efektifitas ini, peneliti meninjau aspek-aspek dari keseluruhan komponen yang ada didalam pelaksanaan program yang dibagi menjadi dimensi input, proses, dan output.

Secara konsep, balita merupakan anak dengan karakteristik usia tertentu. Demikian pula dijelaskan oleh Hanum bahwa "Balita adalah bayi dan anak yang berusia lima tahun kebawah (Hanum Marimbi, 2010). Karasteristik umur yang telah ditentukan tersebut membedakan masa balita dengan masa lainnya dimana pada masa ini terjadi pertumbuhan yang sangat signifikan. Didalam Soetjiningsih (2012) dijelaskan bahwa pertumbuha dasar pada masa balita akan mempengaruhi dan menentukan perkembangan selanjutnya. Sehingga setiap penyimpangan sekecil apapun apabila tidak terdeteksi apalagi tidak ditangani dengan baik, akan mengurangi kualitas Sumber Daya Manusia kelak di kemudian hari.

Mengacu pada Soetjiningsih (2012) perkembangan anak balita memerulukan rangsangan/stimulasi yang berguna agar potensi anak tersbebut dapat berkembang. Hal ini akan optimal bila interaksi sosial diusahakan sesuai dengan kebutuhan anak dalam tahap perkembangannya termasuk sejak bayi berada didalam kandungan. Berdasarkan penjelasan PN. Evelin dan Djamaludin (2010) terdapat tiga kebutuhan anak yang harus dipenuhi oleh orang tua dan keluarga diantaranya: kebutuhan gizi (asuh), kebutuhan emosi dan kasih sayang (asih), dan kebutuhan stimulasi dini (asah). Kebutuhan gizi perlu dipenuhi secara tepat dan berimbang agar tumbuh kembang fisik dan biologis balita berjalan optimal. Kebutuhan emosi dan kasih sayang perlu dipenuhi secara tepat agar anak tumbuh cerdas secara emosi terutama dalam kemampuannya membina hubungan hangat dengan orang lain. Kemudian pemenuhan kebutuhan stimulasi dini secara baik dan benar dapat merangsang kecerdasan majemuk anak.

Hubungan anak dan orang tuanya terutama ibu merupakan sebuah hubungan yang memiliki kedekatan sangat erat. Hal ini dapat diciptakan melalui interaksi yang dilakukan antara ibu dan anak dalam kehidupannya sehari-hari. Fungsi ibu didalam kehidupan rumah tangga bersifat fleksibel dan sangat penting dalam menentukan taraf kesejahteraan keluarga. Namun, salah satu yang menjadi fungsi utama yaitu memberikan 
pengasuhan kepada anak. Orang tua memiliki posisi dan tanggung jawab terbesar dalam hal pengasuhan anak. Seperti yang diungkapkan Sulystiorini (2007) bahwa dalam melakukan tanggung jawabnya, orang tua dituntut untuk memelihara kesehatan anak, memberikan makanan bergizi, memberikan pendidikan dan menciptakan lingkungan psikososial yang kondusif.

Berdasarkan penjelasan yang telah dikemukakan, maka pengasuhan anak yang dilakukan oleh orang tua harus disesuaikan dengan potensi tumbuh kembang anak tersebut. Pendidikan, pengetahuan, dan keterampilan dalam pengasuhan anak merupakan hal utama yang perlu dimiliki oleh orang tua terutama seorang ibu dalam menunjang perkembangan anaknya. Melalui pengetahuan dan keterampilan yang dimilikinya tentang pengasuhan anak, maka ibu dapat memberikan pengasuhan yang sesuai dengan kebutuhan dan proses perkembangan anak balita. Kesesuaian inilah yang menunjukkan bahwa ibu telah memberikan pengasuhan yang berkualitas kepada anak balitanya.

Keluarga merupakan satuan terkecil yang berada di lingkungan masyarakat. Sebagai satuan yang terkecil, interaksi dan hubungan yang dilakukan akan lebih dekat dan intens. Melalui proses belajar antar anggota keluarga selama hidup bersama akhirnya akan menghasilkan nilai-nilai, norma, dan kebudayaan. Sebuah keluarga perlu memiliki ketahanan agar dapat menjalankan fungsi-fungsi pentingnya didalam kehidupan. Berdasarkan UU. No. 52
Tahun 2009 "Ketahanan dan kesejahteraan keluarga adalah kondisi keluarga yang memiliki keuletan dan ketangguhan serta mengandung kemampuan fisik-materil guna hidup mandiri dan mengembangkan diri dan keluarganya untuk hidup harmonis dalam meningkatkan kesejahteraan kebahagiaan lahir dan batin."

Ketahanan keluarga akan tercipta melalui nilai, keterampilan, dan pola interaksi yang dimiliki oleh keluarga tersebut didalam menjalankan kehidupannya sehari-hari. Oleh karena itu pembinaan ketahanan keluarga dilakukan dengan tujuan agar keluarga dapat mengelola sumber daya yang tersedia dalam lingkungan keluarga dan menyelesaikan permasalahan yang dihadapinya secara mandiri. Ketahanan keluarga berkaitan dengan keberfungsian keluarga dalam pembangunan kualitas sumber daya anak. Seperti hasil penelitian Sunarti (2008) yang menunjukkan bahwa ketahanan keluarga mempengaruhi pengasuhan anak dan akibatnya mempengaruhi pertumbuhan dan perkembangan anak.

Dengan demikian keluarga yang memiliki ketahanan memberikan makna bahwa keluarga tersebut telah berfungsi. Sehingga keberfungsian keluarga tersebut bertindak sebagai faktor utama yang mendorong peningkatan taraf kesejahteraan keluarga yang pada akhirnya secara tidak langsung berdampak pada peningkatan kesejahteraan anak. Terwujudnya kesejahteraan anak sangat ditentukan oleh keluarga dan kesejahteraan keluarga itu sendiri sebagai tempat yang paling utama 
dimana anak tumbuh dan berkembang. Oleh sebab itu, keluarga dituntut untuk memberikan suatu tata kehidupan yang layak dan memadai bagi kebutuhan anak sesuai dengan tahap perkembangannya. Melalui nilai, keterampilan, dan pola interaksi yang diterapkan oleh keluarga sebagai gambaran bahwa keluarga tersebut memiliki ketahanan, maka akan mendukung kesesuaian pemenuhan kebutuhan anak sehingga secara linear berdampak pada peningkatan kesejahteraan anak.

Peran pekerja sosial yang sangat vital dan krusial yaitu pada sistem kesejahteraan anak. Anak dan orang tua dalam sistem kesejahteraan anak seringkali diketahui dari sistem lain seperti kesehatan mental dan pendidikan, pekerja sosial bekerja pada setting lain yang mengharuskan untuk memahami benar mengenai isu-isu, kebijakan, dan praktik dalam kesejahteraan anak. (Petr, 2004) Artinya, fokus pekerjaan sosial yaitu penyelarasan kebijakan dan praktik yang dibutuhkan untuk meningkatkan kesejahteraan anak. Peningkatan kesejahteraan anak itu sendiri dilakukan salah satunya melalui pemeliharaan dan pembinaan keluarga.

Pengasuhan adalah sebuah peran yang menuntut dan mengharuskan sebuah tingkatan keterampilan yang penuh disertai dengan dukungan sistem sosial yang kuat. (Collins dkk., 2010) Bagaimanapun juga untuk sebagian besar orang, keterampilan pengasuhan tidak dapat didasari secara insting. Mengacu pada Collins, pekerjaan sosial mempercayai bahwa orang tua dapat mempelajari keterampilan pengasuhan yang lebih efektif. Pekerja sosial keluarga bekerja dengan anggota keluarga untuk meningkatkan kemampuan yang terintegrasi dalam keharmonisan keluarga.

Program pemberdayaan / pembinaan keluarga berangkat dari permasalahan sosial yang dihadapi oleh keluarga. efektifitas pelaksanaan program dapat dikemukakan sebagai suatu pencapaian yang dihasilkan oleh kegiatan-kegiatan yang dilaksanakan didalam program tersebut. Pendapat peserta program dapat dijadikan sebagai ukuran untuk menentukan efektifitas program. Hal tersebut dinyatakan oleh Kerkpatrick yang dikutip oleh Cascio (1995) dalam Tulus (1996) bahwa evaluasi terhadap efektifitas program pelatihan dapat dilakukan, diantaranya melalui reaksi peserta terhadap program yang diikuti. Bermanfaatkah dan puaskah peserta pelatihan terhadap program pelatihan merupakan pertanyaan-pertanyaan yang dapat dijadikan sebagai alat untuk mengukur reaksi peserta terhadap program pelatihan (Tulus, 1996).

Konsep evaluasi memiliki keterkaitan dengan efektifitas dimana keduanya bertumpu pada hasil dari pelaksanaan sebuah kegiatan atau program. Demikian halnya penilaian dalam evaluasi menurut Carol $\mathrm{H}$. Weiss dimaksudkan untuk mengukur efek suatu program dalam mencapai tujuan yang telah ditetapkan. Mengacu pada Katherine (2012), dalam beberapa tahun terakhir teori perubahan pendekatan untuk mengukur efektifitas program telah banyak dianut oleh penyedia dana, evaluator dan 
manajer program sosial. Ada dua alat dalam pengukuran efektifitas program sosial, diantaranya logic models yang mengkaji efektifitas berdasarkan keseluruhan komponen dan theories of change yang mengkaji efektifitas berdasarkan perubahan atau hasil dari pelayanan yang telah diberikan. Melalui dua alat pengukuran efektifitas program sosial yang dikemukakan oleh Katherin (2012), maka pendekatan untuk mengukur efektifitas ini cenderung menggunakan logic models dengan dimensidimensi yang digunakan yaitu input, proses, output.

\section{SIMPULAN}

Berdasarkan penjelasan yang telah dikemukakan pada subbab mengenai ketahanan keluarga, bahwa keluarga yang memiliki ketahanan dapat mendukung pengasuhan anak. Didalam konteks yang sama, peningkatan ketahanan keluarga akan tercapai melalui pelaksanaan program pembinaan ketahanan keluarga dan kesejahteraan keluarga oleh pihak pemerintah setempat dalam hal ini yaitu Badan Pemberdayaan Perempuan dan Keluarga Berencana Kota Bandung. Keluarga yang memiliki ketahanan artinya keluarga tersebut dapat berfungsi untuk mengelola sumber-sumber yang ada dalam rangka penyelesaian masalah yang dihadapinya serta pemenuhan kebutuhan anggota keluarganya. Konsekuensinya, fondasi pekerja sosial keluarga terletak pada prinsip bahwa anak akan mendapatkan pengasuhan yang baik ketika keluarga berfungsi secara optimal.

Keluarga yang memiliki ketahanan akan dapat memberikan pencapaian hasil positif bagi anak walaupun keluarga tersebut dalam keadaan beresiko tinggi. Misalnya seorang anak yang tumbuh di lingkungan tetangga yang beresiko tinggi (di lingkungan kejahatan atau lingkungan pelacuran), tetapi di kemudian hari ia dapat menjadi orang dewasa yang kontributif bagi masyarakat karena keluarga dari anak tersebut memiliki ketahanan. Dengan demikian ketahanan dan kesejahteraan keluarga keduanya dapat memberikan kontribusi penting bagi kesejahteraan anak. sebagaimana pendapat Michelle A. Johnson dan rekan-rekan (2006) bahwa faktor-faktor yang secara signifikan mempengaruhi kesejahteraan anak yaitu keselamatan anak, ketahanan keluarga, kesejahteraan keluarga, kapasitas perlindungan dan pengasuhan anak, serta kemampuan keluarga untuk menjamin keamanan terhadap anak-anaknya.

Berdasarkan pendapat Johnson (2006) dapat diidentifikasi faktor lain yang mempengaruhi kesejahteraan anak yaitu kapasitas orang tua dan keluarga dalam hal pengasuhan dan perlindungan anak. Kapasitas digambarkan melalui pemahaman dan keterampilan ibu dalam mengasuh dan mendidik anak balitanya. Setiap anak terutama pada masa keemasan (balita) perlu mendapatkan pola asuh yang baik agar kebutuhan-kebutuhan dasarnya dapat terpenuhi sehingga anak dapat tumbuh dan berkembang secara wajar. Program Bina 
Keluarga Balita dilaksanakan dengan tujuan utamanya yaitu untuk meningkatkan pemahaman dan keterampilan orang tua mengenai pengasuhan dan pendidikan anak. Melalui peningkatan pemahaman tersebut diharapkan kapasitas pengasuhan anak yang dimiliki oleh orang tua sekaligus keluarga secara otomatis dapat meningkat.

Berdasarkan tujuan dan manfaat program tersebut, maka diperlukan penilaian efektifitas program agar dapat diketahui bagaimana hasil pencapaian program. Dalam mengkaji mengenai efektifitas program Bina Keluarga Balita diperoleh melalui kajian atas dimensi input, proses, dan output. Ketiga dimensi inilah yang dijadikan lingkup penelitian untuk membatasi hal-hal apa saja yang dikaji dalam penelitian ini.

Dimensi yang pertama adalah input (masukan). Input dari pelaksanaan program Bina Keluarga Balita dapat berupa fasilitas sarana dan prasarana yang mencakup seluruh peralatan yang dibutuhkan serta tempat untuk melaksanakan kegiatan, peserta ialah para orang tua balita yang terlibat didalam kegiatan, sumber dana dimana merupakan komponen penting untuk terselengaranya program Bina Keluarga Balita, dan yang terakhir kader bertindak sebagai penyebarluasan informasi mengenai program dan pemberian materi.

Dimensi kedua adalah proses dimana merupakan aspek atau kegiatan yang menambah kegunaan dari komponenkomponen yang telah disebutkan pada dimensi input. Aspek dalam dimensi proses diantaranya metode penyuluhan dan proses kegiatan dari mulai perencanaan hingga evaluasi.

Output (hasil) merupakan keluaran yang dapat dicapai melalui penggunaan input pada proses. Output pelaksanaan program Bina Keluarga Balita dapat berupa peningkatan pemahaman orang tua dalam hal pengasuhan anak, meningkatnya peran serta masyarakat dalam kegiatan Bina Keluarga Balita.

\section{DAFTAR PUSTAKA}

\section{Buku :}

Abdillah Hanafi dan Mulyadi Guntur Waseso. 1984. Penelitian untuk Mengevaluasi Efektifitas Program Kemasyarakatan. Surabaya: Usaha Nasional Surabaya.

Agus Tulus, Moh. 1996. Manajemen Sumber Daya Manusia. Buku Panduan.

Bappenas. 1992. Bab 19. Kependudukan dan Keluarga Berencana

BKKBN. Operasional BKB.

Panduan

BKKBN. (2007). Buku Pegangan Kader Bina Keluarga Balita. Bandung.

BKKBN. (1992). Buku Pegangan Kader KB. Jakarta.

BPPKB Kota Bandung. 2011. Sistimatika Memori Kerja.

Budiyono dan Wayan Koster. 2002. Teori dan Aplikasi Statistika dan Probabilitas. Bandung: PT. Remaja Rosdakarya.

Bungin, Burhan. 2005. Metodologi Penelitian Kuantitatif. Jakarta: Kencana Prenada Media Group.

Collins Donald, Jordan Catheleen, and Heather Coleman. 2010. An Introduction to Family Social Work. USA: Brooks/Cole

Damanik,Juda.2008:4.Pengantar Pekerjaan Sosial.Jakarta:Direktorat Pembinaan SMK 
Jones, Charles O. 1994, Pengantar Kebijakan Publik Terjemahan Ricky Istamto. Jakarta: Roja Grafindo Persada.

Kementrian Sosial, 2009. Glosarium Penyelenggaraan Kesejahteraan Sosial

Mizrahi, Terry and Larry E Davis. 2008. Encyclopedia of Sosial Work $20^{\text {th }}$ Edition.NASW Press: New York

Moekijat, 1981. Manajemen Kepegawaian. Bandung: Mandar Maju.

Pamudji. 1985. Ekologi Administrasi Negara. Jakarta: Bina Aksara.

Petr, Crhristopher G. 2004. Sosial Work with Children and Their Families. New York: Oxford University Press.

PN. Evelin dan Djamaludin. N (2010). Panduan Pintar Merawat Bayi \& Balita. Jakarta : PT Wahyu Media.

S, Kasni Hariwoeryanto, Kebijakan Sosial dan Evaluasi Program Kesejahteraan Sosial, Karya Nusantara, Bandung, 1987.

Sedarmayanti. 2009. Sumber Daya manusia dan produktivitas. Bandung: CV Mandar Maju.

Soekanto, Soedjono. 1989. Teori Sosiologi. Jakarta: Ghalia Indonesia.

Soetjiningsih. 1995. Tumbuh Kembang Anak. EGC. Penerbit Buku Kedokteran.

Sondang P.Siagian, 2001. Manajemen Sumber Daya Manusia. Jakarta: Bumi Aksara.

Sugiyono, 2002. Metode Penelitian Administrasi. Bandung: Alfabeta.

Sugiyono. 2007. "Metode Penelitian Kuantitatif Kualitatif dan R\&D". Bandung: Alfabeta.

Sugiyono, 2003. Statistika untuk Penelitian. Bandung: Alfabeta.

Suyanto, Slamet. 2005. Konsep Dasar Pendidikan Anak Usia Dini. Jakarta: Direktorat Pembinaan Tenaga Kependidikan dan Ketenagaan Perguruan Tinggi.

\section{Jurnal, Hasil Penelitian, Artikel :}

A. Johnson, Michelle et all. 2006: 1. Family Assessment in Child Welfare Services: Instrument Comparisons. Bay Area Sosial Services Consortium and the Zellerbach Family Foundation

Budi Santoso, Irawan. 2004. Evaluasi Pelaksanaan Program Terpadu Pemberdayaan Masyarakat Berperspektif Gender (p2m-bg). Program Studi IImu Adiministrasi Fakultas IImu Sosial dan IImu Politik. Universitas Sebelas Maret.

Child Welfare Information Gateway. 2010. Pdf. Family Engagement melalui www.childwelfare.gov

DepKes RI, 2004. Sistem Kesehatan Nasional 2004, Jakarta.

Gabriel A. 2008. Perilaku keluarga sadar gizi (kadarzi) serta hidup bersih dan sehat ibu kaitannya dengan status gizi dan kesehatan balita di Desa Cikarawang, Bogor [Skripsi]. Bogor : Fakultas Pertanian, Institut Pertanian Bogor.

Heryendi, Wycliffe Timotius. 2013. Efektifitas Program Usaha Peningkatan Pendapatan Keluarga Sejahtera (UPPKS) di Kecamatan Denpasar Barat. Jurusan Ekonomi Pembangunan. Fakultas Ekonomi Universitas Udayana.

Indra, Hendy. 2010. Masalah Kependudukan yang Berhubungan dengan Sosial. Program Studi Geografi. Universitas Muhammadiyah Purwokerto.

Kementerian Sosial, 2009. Rencana Strategis 2010-2014 Kementerian Sosial.

Khaizu, Ingata. 2009. Upaya-Upaya Perlindungan Oleh Organisasi Sosial Keagamaan Lokal Bagi Anak yang Berada pada Pemukiman Rawan untuk Tereksploitasi Secara Ekonomi dan Seksual melalui www.lontar.ui.ac.id

Main, Katherin. 2012. Program Design, A Practical Guide. United Way.

Suharto, Edi. 2007. Menggagas Pelayanan Sosial yang Berkeadilan. 


\section{Website :}

Azuar Juliandi, 2007. Teknik Pengujian Validitas dan Reliabilitas, pdf melalui http://azuarjuliandi.com/elearning/

Fachrudin, Adi. Ketahanan Institusi Keluarga dan Kesejahteraan Anak dalam www.academia.edu
Sunarti, Euis. 2012. Keluarga Berencana dalam Konteks Peningkatan Kualitas Sumber Daya Manusia dan Ketahanan Keluarga melalui www.euissunarti.staff.ipb.ac.id

Rangga, Dayat. 2013. Pekerjaan Sosial Individu dengan Keluarga melalui www.dayatranggambozo.blogspot.com 